\title{
Protective Effect of Aster tataricus L. Extract on the Dermal Cytotoxicity Induced by Sodium Bromate, Oxidant of Hair Dye
}

\author{
Jung-Hwa Chung ${ }^{1, *}$, Gyoung-Wan Lee ${ }^{2, *}$ and Young-Mi Seo ${ }^{2, ; ; *}$ \\ ${ }^{I}$ Sanbon Hospital, School of Medicine, Wonkwang University, Gyeonggi-do 15865, Korea \\ ${ }^{2}$ Department of Nursing, College of Medicine, Wonkwang Health Science University, Iksan 54538, Korea
}

This study evaluated the dermal cytotoxicity of sodium bromate $\left(\mathrm{NaBrO}_{3}\right)$ and the protective effect of Aster tataricus L. (AT) extract against $\mathrm{NaBrO}_{3}$-induced cytotoxicity in the cultured $\mathrm{NIH} 3 \mathrm{~T} 3$ fibroblasts. For this study, it was done the antioxidative effects such as electron donating (ED) activity and lipid peroxidation (LP) activity as well as cell viability. $\mathrm{NaBrO}_{3}$ significantly decreased cell viability in a dose-dependent manner and its $\mathrm{XTT}_{50}$ value was measured at a concentration of $54.4 \mu \mathrm{M}$ in these cultures. The cytotoxicity of $\mathrm{NaBrO}_{3}$ was determined as highly-toxic by Borenfreund and Puerner's toxic criteria. The quercetin, antioxidant significantly increased cell viability against $\mathrm{NaBrO}_{3}$-induced cytotoxicity. Regarding the protective effect of Aster tataricus (AT) L. extract on $\mathrm{NaBrO}_{3}$-induced cytotoxicity, AT extract significantly increased the cell viability, the ED ability and the inhibitory ability of LP. From these findings, it suggested that the oxidative stress is involved in the cytotoxicity of $\mathrm{NaBrO}_{3}$, and $\mathrm{AT}$ extract effectively protected $\mathrm{NaBrO}_{3}$-induced cytotoxicity by antioxidative effects. Conclusively, the natural component like AT extract may be a putative therapeutic agent for the diminution or treatment of the cytotoxicity correlated with oxidative stress like hair dye component, $\mathrm{NaBrO}_{3}$.

Key Words: Antioxidative effect, Cytotoxicity, Natural component, Oxidative stress

\section{서 론}

브롬산나트륨 $\left(\mathrm{NaBrO}_{3}\right)$ 은 염모제 구성 중 과산화수소 $\left(\mathrm{H}_{2} \mathrm{O}_{2}\right)$ 와 함께 색상발현을 도와주는 필수 산화제로 널리 사용되고 있다. 이 중 $\mathrm{NaBrO}_{3}$ 는 $\mathrm{H}_{2} \mathrm{O}_{2}$ 에 비해 두피속까지 침투하여 피부독성이 훨씬 강하지만 $\mathrm{S}$-컬(curl)형성율과 유지력이 뛰어나 높은 선호도를 가지고 있다. 이러한 이 유로 일상생활에서 $\mathrm{NaBrO}_{3}$ 의 반복적인 접촉과 노출로 인 한 독성문제가 관심의 대상으로 떠 오르게 되었다. 브롬 산염의 독성연구로는 생체에서 신장을 비롯한(Park et al., 2011; Ryu et al., 2011), 시각과 청각(Sashiyama et al., 2002;
Suzuki et al., 2018), 모발(Lee and Chang, 2008; Eo et al., 2011) 및 피부(Kim et al., 2014) 등이 있으나 시험관 내에서는 대 식세포에 대한 면역연구를 비롯하여(Guo et al., 2001), 신장 세포에서 DNA 메틸화(Kolli et al., 2019)와 단백질발현 저 해(Kolisetty et al., 2013)와 같은 다양한 손상기전을 초래한 다고 알려져 있다. 그 중, $\mathrm{NaBrO}_{3}$ 대한 산화적 손상에 대 한 연구로는 면역을 비롯한(Guo et al., 2001), 모발(Eo et al., 2011) 또는 신장(Park et al., 2011)에 관한 몇몇 연구가 있으 나 피부세포에 대한 연구는 매우 미흡하다. 근래 $\mathrm{NaBrO}_{3}$ 와 같이 중금속을 포함한 몇몇 화합물이 붕괴 시 과산화 수소 $\left(\mathrm{H}_{2} \mathrm{O}_{2}\right)$ 를 비롯하여 수산기라디칼(-OH) 및 슈퍼옥사이 드라디칼 $\left(\mathrm{O}_{2}{ }^{-}\right)$와 같은 자유라디칼(free radical)을 발생하면

Received: October 29, 2019/Revised: December 10, 2019/ Accepted: December 19, 2019

*Professor

†Corresponding author: Young-Mi Seo. Department of Nursing, College of Medicine, Wonkwang Health Science University, 514 Iksan-daero, Iksan 54538, Korea.

Tel: +82-63-840-1314, Fax: +82-63-840-1319, e-mail: dudn0408@naver.com

(C)The Korean Society for Biomedical Laboratory Sciences. All rights reserved.

@ This is an Open Access article distributed under the terms of the Creative Commons Attribution Non-Commercial License (http://creativecommons.org/licenses/by-nc/3.0/) which permits unrestricted non-commercial use, distribution, and reproduction in any medium, provided the original work is properly cited. 
서 산화적 손상을 일으킨다고 제시된 바 있다(Leonard et al., 2000). 따라서 본 연구에서는 $\mathrm{NaBrO}_{3}$ 의 피부독성에 자 유라디칼이 관여하고 있는지를 알아보기 위하여 피부세포 일종인 배양 $\mathrm{NIH3T3}$ 섬유아세포에 $\mathrm{NaBrO}_{3}$ 를 처리하여 자유라디칼 제거제에 대한 영향을 분석하였다.

최근, 각종 식물성분(phytochemicals) 중에는 항산화를 비 롯한 항염, 항균 등에 유효한 생리활성물질이 다량 함유 되어 있다고 보고되면서 이들 성분에 대한 치료적 연구가 이루어지고 있다(Lee and Seo, 2018). 특히, 식물 중 개미취 (Aster tataricus L., AT)는 국화과(compositae)에 속하는 여러 해살이풀로 우리나라 산지에 널리 서식하고 있다. AT에는 플라보노이드계통(flavonoids)의 쿼세틴(quercetin), 캄페롤 (Kaempferol), 이소플라보노이드계통(isoflavonoids)의 아스 테르사포닌(astersaponin), 프로사포게닌(prosapogenin)을 비 롯하여 페놀화합물인 페루릭산(Ferulic acid)과 그 밖에 스 테롤(sterols), 트리터펜(triterpenes) 등과 같은 다양한 성분 들을 함유하고 있다고 알려져 있어, 항균을 비롯하여 항 산화, 항염에 관련된 질환에 사용되어 왔다(Yang et al., 2015). 이들 성분 중, quercetin이나 kaempferol, astersaponin, prosapogenin과 같은 플라보노이드류(flavonoids)는 강력한 항산화능을 가지고 있다고 알려져 있다(Ng et al., 2003). 지 금까지 $\mathrm{AT}$ 에 대한 연구는 항염을 비롯한 항산화 측면에 서 다수 되어 있으며, 항산화보다는 항염부분에서 더 많 은 분석이 이루어져 있다(Ngabire et al., 2018). 현재, AT의 항산화에 대한 연구를 살펴보면, 당뇨쥐를 이용한 superoxide dismutase (SOD), gluthathion (GSH)의 활성을(Du et al., 2014), 비만쥐를 이용한 catalase (CAT)의 활성을(Yao et al., 2017), 간질쥐를 이용한 LP (lipid peroxidation), SOD, CAT 의 활성에 대한 조사가 있다(Hu et al., 2017). 또한, 배양 세포를 이용한 연구로는 MG63 세포에서 SOD의 활성을 (Choi et al., 2009), 간세포(L-O2)에서 GSH 활성을(Wang et al., 2014), Raw.264.7 세포에서 DPPH-radical 소거능에 대한 조사가 있다(Ngabire et al., 2018). 이에 비하여 피부세포에 서의 항산화 분석은 보기 어렵다. 따라서, 본 연구에서는 $\mathrm{NaBrO}_{3}$ 의 피부독성을 세포수준에서 알아보기 위하여 피 부섬유아세포의 하나인 배양 NIH3T3 섬유아세포를 재료 로 $\mathrm{NaBrO}_{3}$ 의 독성을 자유라디칼에 의한 산화적 손상 측 면에서 조사하였으며, 이의 독성과 관련하여 $\mathrm{AT}$ 추출물의 항산화 영향을 전자공여능(EDA)과 지질과산화(LP) 억제능 을 통하여 알아 보았다.

\section{재료 및 방법}

\section{약제 제조}

본 실험에 사용한 시약으로 $\mathrm{NaBrO}_{3}, 1,1$-diphenyl-2-picrylhydrazyl (DPPH), methyl alcohol, linoleic acid, phosphate phosphate saline (PBS), isopropanol, quercetin, hydrogen peroxide $\left(\mathrm{H}_{2} \mathrm{O}_{2}\right)$, trypsin, ammonium thiocyanate, aluminum nitrate, ethyl alcohol 및 XTT (2,3-bis-[2-methoxy-4-nitro-5-sulfophenyl]2H-tetrazolium-5-caboxanilide, disodium salt)는 Sigma사(St Luios. MO, USA)에서 구입하였다. 또한, $\mathrm{NaBrO}_{3}$ 의 제조는 $\mathrm{XTT}_{50}$ 값을 구하기 위하여 태아소혈청(fetal bovine serum, FBS, Gibco, USA)이 없는 최소필수배지(minimum essential medium, MEM, Gibco, USA)를 사용하여 30, 50, 70, $100 \mu \mathrm{M}$ 의 각 저장액을 만들어 사용하였다. XTT는 $\mathrm{PBS}$ 를 이용하 여 $50 \mu \mathrm{g} / \mathrm{mL}$ 의 저장액을 만든 후 냉암소에 보관한 다음 필요한 양을 직접 배양액에 첨가 또는 희석하여 사용하 였다.

\section{AT 채취 및 추출}

전북 야산에서 봄과 가을에 걸쳐 $\mathrm{AT}$ 전초를 채취하여 대학부설 생명자원과학연구소에서 동정 확인 후 사용하였 다. 채취한 전초는 잘 씻은 후 햇볕에서 말려 일정 길이 로 잘라 냉암소에 보관하여 시료로 사용하였다. 보관 중 인 시료 $73.9 \mathrm{~g}$ 을 잘게 파쇄한 다음 시료와 약 $250 \mathrm{~mL}$ 의 증류수를 $1,000 \mathrm{~mL}$ 의 환저플라스크에 함께 넣고 3시간 동안 가열하였다. 위의 과정을 4 회 반복 추출하여 여과한 다음 $574 \times \mathrm{g}$ 에서 30 분 동안 원침시켰다. 원침 후 진공농 축기에서 감압농축시킨 다음 $3.7 \mathrm{~g}$ 의 시료를 얻었으며, 이 때 수율은 $5.0 \%$ 로 나타났다.

\section{세포 배양 및 생존율(cell viability) 분석}

NIH3T3 섬유아세포주(ATCC, CRL 1658)의 배양은 Jung et al. (2014)의 방법에 따라 trypsin으로 부착된 세포를 배양 용기로부터 떼어 냈다. 떨어진 세포들은 원침 후 $10 \% \mathrm{FBS}$ 가 함유된 MEM 배양액에 넣어 잘 섞은 한 다음 $1 \times$ $10^{5} \mathrm{cells} / \mathrm{well}$ 이 되도록 산정, 세포를 96-well 배양 용기에 배분하였다. 배분된 세포들은 $36^{\circ} \mathrm{C}, 5 \% \mathrm{CO}_{2}$ 로 조절된 항 온기 내에서 72시간 동안 배양하였다. 세포생존율 분석은 Mosmann (1983)의 방법에 따라, 농도별로 세포에 약제를 처리하여 일정 시간 동안 배양한 다음 실험 당일 제조한 $\mathrm{XTT}(50 \mu \mathrm{g} / \mathrm{mL})$ 를 well 당 $10 \mu \mathrm{L}$ 씩 넣어 $36^{\circ} \mathrm{C}$ 로 조절된 
항온기에서 4시간 동안 배양하였다. 배양이 완료된 후 isopropanol을 넣어 실온에서 정치한 다음 ELISA reader (Spectra max 250, Molecular Devices, Sunnyvale, USA)로 $450 \mathrm{~nm}$ 에서 흡광도를 측정하여 대조군과 비교 조사하였 다. $\mathrm{XTT}_{50}$ 값의 산출은 회귀직선식에 의하여 산출하였다.

\section{$\mathrm{NaBrO}_{3}$ 의 독성 및 처리}

배양 중인 NIH3T3 섬유아세포에 $\mathrm{NaBrO}_{3}$ 가 25 55 $\mu \mathrm{M}$ 농도로 각각 포함된 배양액에서 세포를 48시간 동안 배양 한 후 세포생존율을 대조군과 비교 조사하였다. 또한, 세 포독성의 $\mathrm{XTT}_{50}$ 값을 측정한 후 이를 본 실험분석에 사용 하였다.

\section{Quercetin의 항산화능 측정 및 $\mathrm{NaBrO}_{3}$ 에 대한 영향}

항산화제인 quercetin의 항산화능을 조사하기 위하여 활 성산소의 일종인 $25 \mu \mathrm{M} \mathrm{H}_{2} \mathrm{O}_{2}$ 를 배양세포를 처리하기 2시 간 전에 quercetin이 $15 \mu \mathrm{M}$ 과 $25 \mu \mathrm{M}$ 의 농도로 각각 포함 된 배양액에서 세포를 처리한 후 세포생존율을 대조군과 비교 조사하였다. 또한, $\mathrm{NaBrO}_{3}$ 에 대한 quercetin의 영향을 조사하기 위하여 $\mathrm{XTT}_{50}$ 농도의 $\mathrm{NaBrO}_{3}$ 를 배양세포에 처 리하기 2시간 전에 quercetin이 각각 $15 \mu \mathrm{M}$ 과 $25 \mu \mathrm{M}$ 로 포 함된 배양액에서 세포를 배양한 다음 세포생존율에 의하 여 대조군과 비교 조사하였다.

\section{AT 추출물의 세포독성 측정 및 추출물 처리}

$\mathrm{AT}$ 추출물에 대한 독성 조사를 위하여 추출물이 각각 $80 \sim 140 \mu \mathrm{g} / \mathrm{mL}$ 로 각각 포함된 배양액에서 48 시간 동안 배양한 후 대조군과 세포생존율을 비교 조사하였다. 이 때 추출물의 최대허용한계농도를 측정 후 한계농도 바로 이 하 농도인 $100 \mu \mathrm{g} / \mathrm{mL}$ 와 $120 \mu \mathrm{g} / \mathrm{mL}$ 를 분석에 사용하였다. 또한, $\mathrm{NaBrO}_{3}$ 에 대한 $\mathrm{AT}$ 추출물의 영향을 조사하기 위하 여 배양세포에 $\mathrm{XTT}_{50}$ 농도의 $\mathrm{NaBrO}_{3}$ 를 처리하기 2시간 전에 $100 \mu \mathrm{g} / \mathrm{mL}$ 와 $120 \mu \mathrm{g} / \mathrm{mL}$ 의 추출물을 각각 배양세포 에 처리한 다음 이의 영향을 세포생존율에 의하여 대조군 과 비교 조사하였다.

\section{AT 추출물의 성분함량 분석}

A.O.A.C. (2005) 방법에 의한 폴리페놀 분석을 위하여 추출시료 $0.2 \mathrm{~mL}$ 에 phenol reagent $0.2 \mathrm{mM}$ 를 첨가하여 3 분 동안 정치하였다. 정치 완료 후 $0.4 \mathrm{~mL} \mathrm{NaBrO}$ 를 가하여 1 시간 동안 반응시킨 다음 ELISA reader로 $725 \mathrm{~nm}$ 에서 흡광도를 측정하였다. 표준시약으로 tannic acid를 이용하
여 검량곡선을 작성하였다. 플라보노이드 분석은 Nieva Moreno et al. (2000)의 방법에 의해, 시료용액 $0.1 \mathrm{~mL}$ 에 $10 \%$ aluminum nitrate와 $1 \mathrm{M}$ potassium acetate 혼합물 $0.2 \mathrm{~mL}$ 에 에탄올 $4.7 \mathrm{~mL}$ 를 가하여 $25^{\circ} \mathrm{C}$ 에서 40 분 동안 반응 후 ELISA reader로 $415 \mathrm{~nm}$ 에서 흡광도를 측정하였다. 표준시 약으로는 rutin을 이용하여 검량곡선을 작성하였다.

\section{전자공여(electron donating, ED) 활성 측정}

$\mathrm{ED}$ 활성의 측정은 Blois (1958)의 방법에 의해, 메탄올 시료에 $0.3 \mathrm{mM} \mathrm{DPPH}$ 메탄올 용액 $100 \mathrm{~mL}$ 를 가하여 30 분 동안 정치하였다. 정치 완료 후 ELISA reader로 $517 \mathrm{~nm}$ 에 서 흡광도를 측정하였고, $\mathrm{ED}$ 활성은 대조군에 대한 백분 율로 하였으며 quercetin을 양성대조군으로 하여 비교 조 사하였다. 또한, 전자공여능 $(\%)=100-[$ (시료첨가군의 흡광 도/무첨가군의 흡광도) $\times 100$ ]으로 나타냈다.

\section{지질과산화(lipid peroxidation, LP) 활성 측정}

LP 활성 측정은 Kikuzaki and Nakatani (1993)의 방법에 따라, 시료 $3.9 \mathrm{~mL}$ 를 에탄올과 혼합하고 에탄올에 녹인 $2.52 \%$ linoleic acid와 0.05 M PBS (pH 7.0) 용액 $12.1 \mathrm{~mL}$ 를 첨가하여 $40^{\circ} \mathrm{C}$ 에서 24 시간 동안 배양하였다. 배양 후 에 탄올과 $30 \%$ ammonium thiocyanate로 처리한 다음 $0.02 \mathrm{M}$ ferrous chloride $0.1 \mathrm{~mL}$ 를 가하여 실온에서 3 분 동안 정치 하였다. 정치 완료 후 ELISA reader로 $500 \mathrm{~nm}$ 에서 흡광도 를 측정하였다. 증류수를 대조군으로 사용하였으며, quercetin을 양성대조군으로 하여 비교 조사하였다. LP 활성은 대조군에 대한 백분율로 하였다. 또한, 지질과산화 저해 능 $(\%)=100-[($ 시료첨가군의 흡광도/무첨가군의 흡광도 $) \times$ 100]으로 나타냈다.

\section{통계 처리}

실험결과는 SPSS/WIN 18.0을 이용하여 mean $\pm \mathrm{SD}$ 로 표시하였다. 실험결과에 대해 one way ANOVA를 시행하 였고 Tukey HSD으로 사후분석을 하였고, 유의수준은 $P<$ 0.05 에서 채택하였다.

\section{결 과}

\section{$\mathrm{NaBrO}_{3}$ 의 세포독성 측정}

$\mathrm{NaBrO}_{3}$ 의 독성을 알아보기 위하여 배양 $\mathrm{NIH} 3 \mathrm{~T} 3$ 섬유 아세포에 25 55 $\mu \mathrm{M}$ 농도로 $\mathrm{NaBrO}_{3}$ 가 각각 포함된 배양 액에서 세포를 48시간 동안 처리한 결과, $\mathrm{NaBrO}_{3}$ 는 처리 
Table 1. The cytotoxicity of sodium bromate $\left(\mathrm{NaBrO}_{3}\right)$ on cultured NIH3T3 fibroblasts by XTT assay

\begin{tabular}{lccccc}
\hline \hline $\begin{array}{c}\text { Concentrations } \\
\text { of } \begin{array}{c}\mathrm{NaBrO}_{3} \\
(\mu \mathrm{M})\end{array}\end{array}$ & $\begin{array}{c}\text { XTT assay } \\
(450 \mathrm{~nm})\end{array}$ & $F$ & $P$ & $\begin{array}{c}\text { Tukey } \\
\text { HSD }\end{array}$ \\
\cline { 2 - 3 } & $\begin{array}{c}\text { Mean } \pm \mathrm{SD} \\
\mathrm{Control}^{\mathrm{a}}\end{array}$ & $0.50 \pm 0.05$ & & & \\
$25 \mu \mathrm{M}^{\mathrm{b}}$ & $0.35 \pm 0.04$ & & & & \\
$40 \mu \mathrm{M}^{\mathrm{c}}$ & $0.30 \pm 0.04$ & 62.96 & $<.001$ & $\mathrm{a}>\mathrm{b}>\mathrm{c}>\mathrm{d}$ \\
$55 \mu \mathrm{M}^{\mathrm{d}}$ & $0.25 \pm 0.02$ & & & \\
\hline
\end{tabular}

The data indicate the mean \pm SD for triplicate experiments Abbreviation: $\mathrm{NaBrO}_{3}$, Sodium bromate

Table 2. The antioxidative ability of quercetin on the hydrogen peroxide $\left(\mathrm{H}_{2} \mathrm{O}_{2}\right)$ in cultured NIH3T3 fibroblasts

\begin{tabular}{lccccc}
\hline \hline $\begin{array}{c}\text { Concentrations } \\
\text { of querce } \\
(\mu \mathrm{M})\end{array}$ & $\begin{array}{c}\text { XTT assay } \\
(450 \mathrm{~nm})\end{array}$ & $F$ & $P$ & $\begin{array}{c}\text { Tukey } \\
\text { HSD }\end{array}$ \\
\cline { 2 - 2 } & Mean $\pm \mathrm{SD}$ & & & \\
\hline Control $^{\mathrm{a}}$ & $0.85 \pm 0.05$ & & & \\
Positive control $^{\mathrm{b}}$ & $0.37 \pm 0.02$ & & & \\
$15 \mu \mathrm{M}^{\mathrm{c}}$ & $0.61 \pm 0.02$ & & & & \\
$25 \mu \mathrm{M}^{\mathrm{d}}$ & $0.73 \pm 0.03$ & & & \\
\hline
\end{tabular}

The data indicate the mean \pm SD for triplicate experiments Abbreviation: Positive control: $25 \mu \mathrm{M} \mathrm{H}_{2} \mathrm{O}_{2}$; querce, Quercetin; $\mathrm{H}_{2} \mathrm{O}_{2}$, Hydrogen peroxide

한 농도에 의존적으로 세포생존율을 대조군에 비하여 유 의하게 감소하며 독성을 나타냈다 $(P<0.001)$. 대조군에 비 해 각각 $70 \%, 60 \%, 50 \%$ 의 세포생존율을 보여 $\mathrm{XTT}_{50}$ 값은 $55 \mu \mathrm{M}$ 의 처리에서 나타난 것을 확인하였다(Table 1). 세포 독성에 대한 사후분석 결과 $55 \mu \mathrm{M}, 40 \mu \mathrm{M}, 25 \mu \mathrm{M}$, 대조군 의 순으로 세포독성이 높은 것으로 나타났다. $\mathrm{NaBrO}_{3}$ 의 독성은 Borenfreund와 Puerner (1985)의 독성판정에 따라 고독성으로 나타났다.

\section{Quercetin의 항산화능 측정}

Quercetin의 항산화능을 조사하기 위하여 $25 \mu \mathrm{M}$ 의 $\mathrm{H}_{2} \mathrm{O}_{2}$ 를 배양세포에 처리하기 전에 quercetin이 각각 $15 \mu \mathrm{M}$ 과 $25 \mu \mathrm{M}$ 로 포함된 배양액에서 2시간 동안 전 처리하였다. 그 결과, $25 \mu \mathrm{M}$ 의 $\mathrm{H}_{2} \mathrm{O}_{2}$ 만을 처리한 경우 대조군에 비하여 세포생존율이 $43.5 \%(0.37 \pm 0.02)$ 로 나타난 반면, $15 \mu \mathrm{M}$ 과 $25 \mu \mathrm{M}$ 의 quercetin의 처리에서는 각각 $71.8 \%(0.61 \pm 0.02)$ 와 $85.9 \%(0.73 \pm 0.03)$ 로 나타나 이는 $\mathrm{H}_{2} \mathrm{O}_{2}$ 만을 처리에 비하여 모두 유의한 세포생존율 증가를 나타냈다 $(P<0.001)$ (Table 2). Quercetin의 항산화능의 사후분석 결과 대조군, $25 \mu \mathrm{M}$
Table 3. The effect of quercetin on the cytotoxicity induced by sodium bromate $\left(\mathrm{NaBrO}_{3}\right)$ in cultured NIH3T3 fibroblasts

\begin{tabular}{lccccc}
\hline \hline $\begin{array}{c}\text { Concentrations } \\
\text { of querce } \\
(\mu \mathrm{M})\end{array}$ & $\begin{array}{c}\text { XTT assay } \\
(450 \mathrm{~nm})\end{array}$ & $F$ & $P$ & $\begin{array}{c}\text { Tukey } \\
\text { HSD }\end{array}$ \\
\cline { 2 - 3 } & Mean $\pm \mathrm{SD}$ & & & \\
\hline Control $^{\mathrm{a}}$ & $0.78 \pm 0.10$ & & & \\
Positive control $^{\mathrm{b}}$ & $0.31 \pm 0.03$ & 116.60 & $<.001$ & $\mathrm{a}>\mathrm{d}, \mathrm{c}>\mathrm{b}$ \\
$15 \mu \mathrm{M}^{\mathrm{c}}$ & $0.65 \pm 0.02$ & & & \\
$25 \mu \mathrm{M}^{\mathrm{d}}$ & $0.70 \pm 0.03$ & & & \\
\hline
\end{tabular}

The data indicate the mean \pm SD for triplicate experiments Abbreviation: Positive control: $55 \mu \mathrm{M} \mathrm{NaBrO} 3\left(\mathrm{XTT}_{50}\right)$; querce, Quercetin; $\mathrm{NaBrO}_{3}$, Sodium bromate

quercetin, $15 \mu \mathrm{M}$ quercetin, $25 \mu \mathrm{M} \mathrm{H}_{2} \mathrm{O}_{2}$ 순으로 세포생존율이 높음을 알 수 있었다. $\mathrm{H}_{2} \mathrm{O}_{2}$ 는 독성이 강한 자유라디칼의 일종으로, 자유라디칼 제거제인 quercetin이 $\mathrm{H}_{2} \mathrm{O}_{2}$ 의 산화적 손상을 유의하게 방어함으로서 강력한 항산화제임이 증명 되었다(Chun et al., 2002).

\section{$\mathrm{NaBrO}_{3}$ 의 독성에 대한 quercetin의 영향}

$\mathrm{NaBrO}_{3}$ 의 세포독성에 대한 항산화제인 quercetin의 영향 을 알아보기 위하여 $\mathrm{NaBrO}_{3}$ 의 $\mathrm{XTT}_{50}$ 농도를 배양세포에 처리하기 전에 quercetin이 각각 $15 \mu \mathrm{M}$ 과 $25 \mu \mathrm{M}$ 로 포함된 배양액에서 2 시간 동안 전 처리하였다. 그 결과, $\mathrm{XTT}_{50}$ 농 도의 $\mathrm{NaBrO}_{3}$ 만의 처리에서는 세포생존율이 대조군에 비 하여 $39.7 \%(0.31 \pm 0.03)$ 로 나타난 것에 비하여 $15 \mu \mathrm{M}$ 과 $25 \mu \mathrm{M}$ quercetin의 처리에서는 각각 $83.3 \%$ (0.65 \pm 0.02$)$ 와 $89.7 \%(0.70 \pm 0.03)$ 로 나타났다 $(P<0.001)$ (Table 3$). \mathrm{NaBrO}_{3}$ 의 세포독성에 대한 항산화제인 quercetin의 영향에 대한 사후분석 결과 대조군, $25 \mu \mathrm{M}$ quercetin과 $15 \mu \mathrm{M}$ quercetin, $\mathrm{NaBrO}_{3}\left(\mathrm{XTT}_{50}\right)$ 순으로 세포생존율이 높은 것을 알 수 있 었다. Qercetin이 강력한 자유라디칼 제거제임이 확인된 바 (Chun et al., 2002), quercetin이 유의하게 $\mathrm{NaBrO}_{3}$ 의 독성을 방어함으로서 $\mathrm{NaBrO}_{3}$ 의 독성에 자유라디칼이 관여하고 있음을 제시하였다.

\section{AT 추출물의 세포독성}

$\mathrm{AT}$ 추출물에 대한 독성분석을 위하여 $\mathrm{AT}$ 추출물이 각 각 80 140 $\mu \mathrm{g} / \mathrm{mL}$ 로 포함된 배양액에서 배양한 결과 80 $\mu \mathrm{g} / \mathrm{mL}$ 와 $100 \mu \mathrm{g} / \mathrm{mL}$ 처리에서는 세포생존율이 대조군인 $100 \%(0.67 \pm 0.03)$ 에 비하여 $98.5 \%(0.66 \pm 0.03)$ 와 $95.5 \%$ $(0.64 \pm 0.03)$ 로 각각 나타났다. 또한, $120 \mu \mathrm{g} / \mathrm{mL}$ 와 $140 \mu \mathrm{g} /$ $\mathrm{mL}$ 에서는 추출물 처리에서는 $94.0 \%$ (0.63 \pm 0.01$)$ 와 $88.1 \%$ 
Table 4. The cytotoxicity of Aster tataricus L. (AT) extract on cultured NIH3T3 fibroblasts by XTT assay

\begin{tabular}{|c|c|c|c|c|}
\hline \multirow{2}{*}{$\begin{array}{c}\text { Concentrations } \\
\text { of AT extract } \\
(\mu \mathrm{g} / \mathrm{mL})\end{array}$} & $\begin{array}{l}\text { XTT assay } \\
(450 \mathrm{~nm})\end{array}$ & \multirow[t]{2}{*}{$F$} & \multirow[t]{2}{*}{$P$} & \multirow{2}{*}{$\begin{array}{l}\text { Tukey } \\
\text { HSD }\end{array}$} \\
\hline & Mean \pm SD & & & \\
\hline Control $^{\mathrm{a}}$ & $0.67 \pm 0.03$ & \multirow{5}{*}{7.54} & \multirow{5}{*}{$<.001$} & \multirow{5}{*}{$a>e$} \\
\hline $80 \mu \mathrm{g} / \mathrm{mL}^{\mathrm{b}}$ & $0.66 \pm 0.03$ & & & \\
\hline $100 \mu \mathrm{g} / \mathrm{mL}^{\mathrm{c}}$ & $0.64 \pm 0.03$ & & & \\
\hline $120 \mu \mathrm{g} / \mathrm{mL}^{\mathrm{d}}$ & $0.63 \pm 0.01$ & & & \\
\hline $140 \mu \mathrm{g} / \mathrm{mL}^{\mathrm{e}}$ & $0.59 \pm 0.05$ & & & \\
\hline
\end{tabular}

The data indicate the mean \pm SD for triplicate experiments Abbreviation: AT, Aster tataricus L.

$(0.59 \pm 0.05)$ 로 각각 나타났다 $(P<0.001)$ (Table 4) (Fig. 1). AT 추출물에 대한 독성분석 사후분석 결과 $80 \mu \mathrm{g} / \mathrm{mL}, 100 \mu \mathrm{g} /$ $\mathrm{mL}, 120 \mu \mathrm{g} / \mathrm{mL}$ 간에는 통계적으로 차이가 없었으나 120 $\mu \mathrm{g} / \mathrm{mL}, 100 \mu \mathrm{g} / \mathrm{mL}, 80 \mu \mathrm{g} / \mathrm{mL}$ 순으로 세포생존율이 높았다. 또한 $80 \mu \mathrm{g} / \mathrm{mL}$ 는 대조군과 통계적인 차이가 없었으며, 120 $\mu \mathrm{g} / \mathrm{mL}$ 와 $140 \mu \mathrm{g} / \mathrm{mL}$ 와도 통계적인 차이가 없었다. 그러나 대조군과 $140 \mu \mathrm{g} / \mathrm{mL}$ 의 세포생존율이 통계적으로 차이를 보여, 대조군에 비하여 유의한 세포생존율의 감소를 나타 내는 최대허용한계농도는 $140 \mu \mathrm{g} / \mathrm{mL}$ 이상에서 나타나는 것으로 확인됨에 따라 본 실험에서는 $\mathrm{AT}$ 잎 추출물을 140 $\mu \mathrm{g} / \mathrm{mL}$ 이하의 농도로 사용하였다. 최대허용한계농도는 시 료 추출물의 종류와 처리하는 세포종에 따라 차이가 나타 나는 경향이 있다(Lee et al., 2018).

\section{AT 추출물의 성분함량 분석}

AT 추출물의 함량 조사에 있어서 폴리페놀의 함량은 $46.8 \mathrm{mg} / \mathrm{g}$ 으로 나타났으며, 플라보노이드 함량은 $23.9 \mathrm{mg}$ $/ \mathrm{g}$ 으로 각각 나타났다(Fig. 2). AT와 비슷한 성분과 함량을 함유하고 있는 한련초나 지금초도 항산화능력이 뛰어난 것으로 보고되었다(Lee and Seo, 2018).

\section{$\mathrm{NaBrO}_{3}$ 의 세포독성에 대한 $\mathrm{AT}$ 추출물의 영향}

AT 추출물이 $\mathrm{NaBrO}_{3}$ 의 세포독성에 미치는 영향을 조 사하기 위하여 배양세포에 $\mathrm{XTT}_{50}$ 농도의 $\mathrm{NaBrO}_{3}$ 를 처리 하기 전에 $100 \mu \mathrm{g} / \mathrm{mL}$ 와 $120 \mu \mathrm{g} / \mathrm{mL}$ 의 $\mathrm{AT}$ 추출물을 각각 처리한 결과, $\mathrm{NaBrO}_{3}$ 의 처리에서는 세포생존율이 대조군 에 비하여 $41.6 \%(0.37 \pm 0.03)$ 로 나타난데 비하여 $100 \mu \mathrm{g} /$ $\mathrm{mL}$ 추출물 처리에서는 $52.8 \%(0.47 \pm 0.02)$ 로 나타났다. 또 한 $120 \mu \mathrm{g} / \mathrm{mL}$ 추출물 처리에서는 $69.7 \%(0.62 \pm 0.05)$ 로 나 타나 $\mathrm{NaBrO}_{3}$ 만의 처리에 비하여 유의한 증가를 보였다

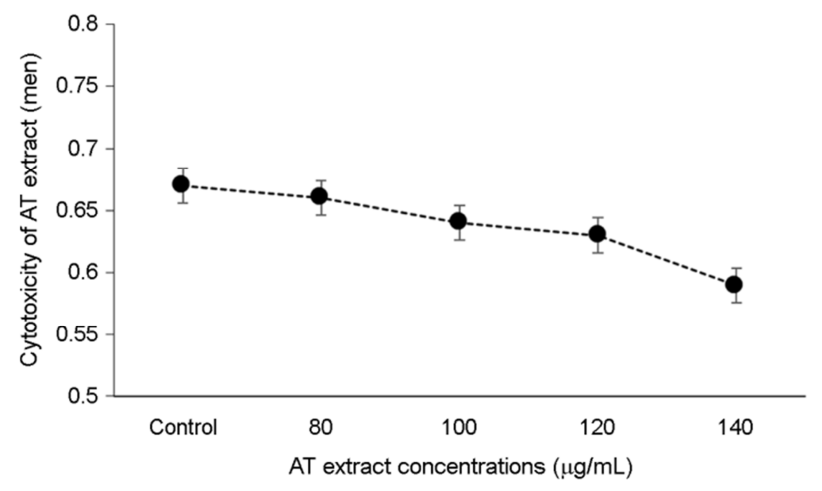

Fig. 1. The cytotoxicity of Aster tataricus L. (AT) extract on cultured NIH3T3 fibroblasts. Cultured cells were incubated with AT extract at concentrations of $80,100,120$ and $140 \mu \mathrm{g} / \mathrm{mL}$, respectively. The data indicate the mean $\pm \mathrm{SD}$ for triplicate experiments. Significantly different from the control.

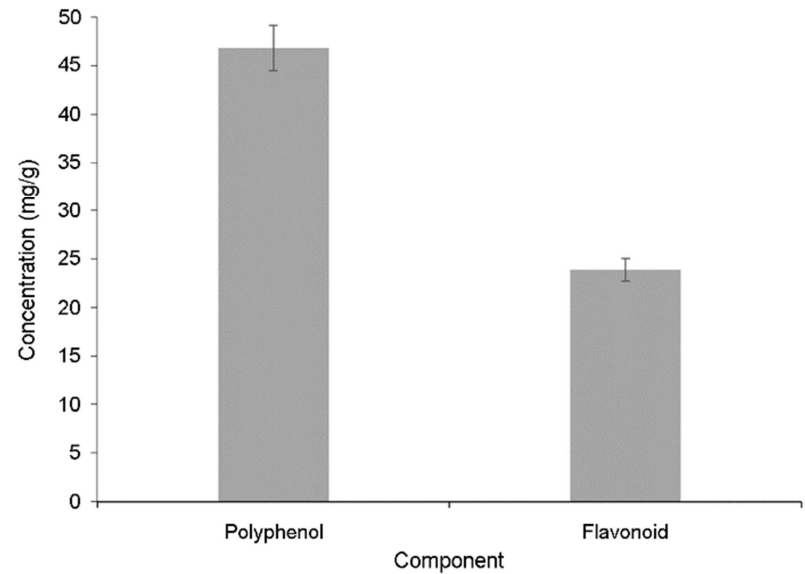

Fig. 2. The component of Aster tataricus L. (AT) extract. Data are mean \pm SD. The data indicate the mean \pm SD for triplicate experiments.

$(P<0.001)$ (Table 5). AT 추출물이 $\mathrm{NaBrO}_{3}$ 의 세포독성에 미 치는 영향에 대한 사후분석 결과 대조군, $120 \mu \mathrm{g} / \mathrm{mL} \mathrm{AT}$ 추 출물, $100 \mu \mathrm{g} / \mathrm{mL}$ AT 추출물, $\mathrm{NaBrO}_{3}$ 순으로 세포생존율이 높게 나타났다.

이는 AT 추출물이 본 연구에서 행한 자유라디칼 소거 능인 전자공여능(EDA)과 산화적 손상에 의한 막지질과산 화 반응을 억제하는 지질과산화(LP)억제능과 같은 항산 화능이 있음이 확인된 결과이다(Blois, 1958; Kikuzaki and Nakatani, 1993).

\section{$\mathrm{ED}$ 활성 측정}

$\mathrm{ED}$ 활성을 측정하기 위하여 $100 \mu \mathrm{g} / \mathrm{mL}$ 와 $120 \mu \mathrm{g} / \mathrm{mL}$ 농 
Table 5. The protective effect of Aster tataricus L. (AT) extract on the cytotoxicity induced by sodium bromate $\left(\mathrm{NaBrO}_{3}\right)$ in cultured NIH3T3 fibroblaststs

\begin{tabular}{lccccc}
\hline \hline $\begin{array}{c}\text { Concentrations } \\
\text { of AT extract } \\
(\mu \mathrm{g} / \mathrm{mL})\end{array}$ & $\begin{array}{c}\text { XTT assay } \\
(450 \mathrm{~nm})\end{array}$ & $F$ & $P$ & $\begin{array}{c}\text { Tukey } \\
\text { HSD }\end{array}$ \\
\cline { 2 - 2 } & $\begin{array}{c}\text { Mean } \pm \mathrm{SD} \\
\text { Control }^{\mathrm{a}}\end{array}$ & & & \\
Positive control $^{\mathrm{b}}$ & $0.89 \pm 0.09$ & & & \\
$100 \mu \mathrm{g} / \mathrm{mL}^{\mathrm{c}}$ & $0.37 \pm 0.03$ & & & \\
$120 \mu \mathrm{g} / \mathrm{mL}^{\mathrm{d}}$ & $0.47 \pm 0.02$ & & & & \\
\hline
\end{tabular}

The data indicate the mean \pm SD for triplicate experiments Abbreviation: Positive control: $55 \mu \mathrm{M} \mathrm{NaBrO}_{3}$; AT, Aster tataricus L.; $\mathrm{NaBrO}_{3}$, Sodium bromate

Table 6. The electron donating (ED) activity of Aster tataricus L. (AT) extract determined at a wavelength of $517 \mathrm{~nm}$

\begin{tabular}{lccccc}
\hline \hline $\begin{array}{c}\text { Concentrations } \\
\text { of AT extract } \\
(\mu \mathrm{g} / \mathrm{mL})\end{array}$ & $\begin{array}{c}\text { ED activity } \\
(517 \mathrm{~nm})\end{array}$ & $F$ & $P$ & $\begin{array}{c}\text { Tukey } \\
\text { HSD }\end{array}$ \\
\cline { 2 - 2 } Control $^{\mathrm{a}}$ & Mean $\pm \mathrm{SD}$ & & & \\
Positive control $^{\mathrm{b}}$ & $0.73 \pm 0.03$ & & & \\
$100 \mu \mathrm{g} / \mathrm{mL}^{\mathrm{c}}$ & $0.12 \pm 0.01$ & & & \\
$120 \mu \mathrm{g} / \mathrm{mL}^{\mathrm{d}}$ & $0.58 \pm 0.02$ & 837.06 & $<.001$ & $\mathrm{a}>\mathrm{c}, \mathrm{d}>\mathrm{b}$ \\
\hline
\end{tabular}

The data indicate the mean \pm SD for triplicate experiments Abbreviation: Positive control: $25 \mu \mathrm{M}$ quercetin $\left(\mathrm{XTT}_{50}\right)$; AT, Aster tataricus L.; querce, Quercetin; ED, Electron donating

도의 AT 추출물 시료를 처리하여 분석한 결과 $100 \mu \mathrm{g} /$ $\mathrm{mL}$ 농도 처리에서는 활성이 대조군에 비하여 $79.5 \%$ 로 나타났으며, $120 \mu \mathrm{g} / \mathrm{mL}$ 의 처리에서는 $75.3 \%$ 로 나타났다 (Table 6). 따라서, $100 \mu \mathrm{g} / \mathrm{mL}$ 와 $120 \mu \mathrm{g} / \mathrm{mL}$ 농도에서 전자공 여능은 각각 $20.5 \%$ 와 $24.7 \%$ 로 나타나 이는 대조군에 비 하여 모두 유의한 공여능의 증가를 나타냈다. 특히, $120 \mu \mathrm{g}$ $/ \mathrm{mL}$ 농도에서는 양성대조군인 quercetin의 전자공여능인 $83.6 \%(P<0.001)$ 의 $25 \%$ 이상으로 나타났다(Fig. 3$). \mathrm{ED}$ 활 성 사후분석 결과 quercetin, $120 \mu \mathrm{g} / \mathrm{mL} \mathrm{AT}$ 추출물과 $100 \mu \mathrm{g}$ $/ \mathrm{mL}$ AT 추출물, 대조군 순으로 전자공여능이 높은 것으 로 나타났다. 전자공여능(EDA)은 산화를 억제하기 때문에 $\mathrm{DPPH}$-라디칼 소거능과 같은 의미로, $\mathrm{AT}$ 추출물의 $\mathrm{EDA}$ 가 대조군에 비하여 유의하게 나타남으로써 추출물이 자유라 디칼을 제거하는 높은 소거능을 가지고 있음을 알 수 있 었다(Blois, 1958).

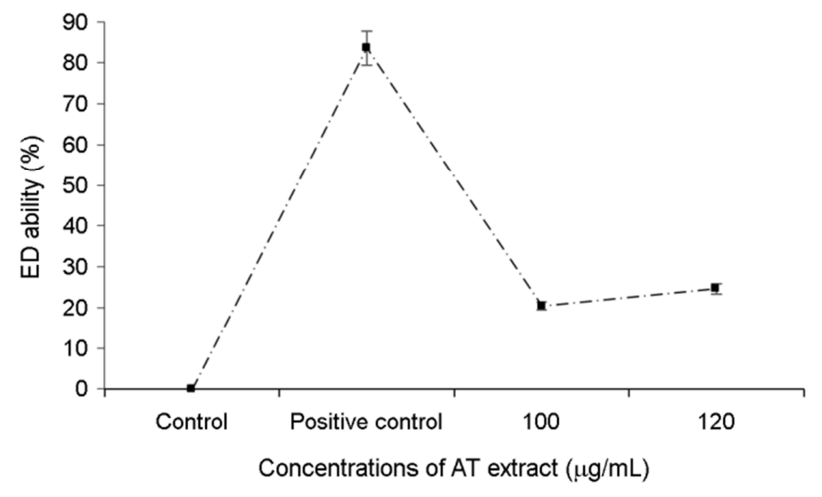

Fig. 3. The electron donating (ED) ability of Aster tataricus $\mathbf{L}$. (AT) extract determined at a wavelength of $517 \mathrm{~nm}$. The data indicate the mean $\pm \mathrm{SD}$ for triplicate experiments. Positive control: $25 \mu \mathrm{M}$ quercetin $\left(\mathrm{XTT}_{50}\right)$.

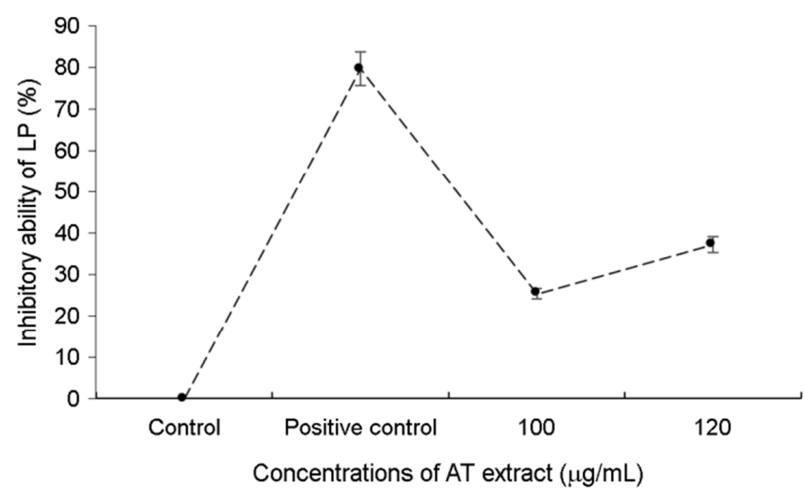

Fig. 4. The inhibitory ability of lipid peroxidation (LP) of Aster tataricus L. (AT) extract determined at a wavelength of $500 \mathrm{~nm}$. The data indicate the mean \pm SD for triplicate experiments. Positive control: $25 \mu \mathrm{M}$ quercetin $\left(\mathrm{XTT}_{50}\right)$.

\section{$\mathrm{LP}$ 활성 측정}

$\mathrm{AT}$ 추출물에 대한 LP 활성 측정을 위하여 $100 \mu \mathrm{g} / \mathrm{mL}$ 와 $120 \mu \mathrm{g} / \mathrm{mL}$ 의 농도의 추출물 시료를 각각 분석한 결과 $100 \mu \mathrm{g} / \mathrm{mL}$ 추출물의 처리에서는 $\mathrm{LP}$ 활성이 $74.6 \%$ 로 나타 났으며, $120 \mu \mathrm{g} / \mathrm{mL}$ 의 처리에서는 $62.7 \%$ 로 나타났다(Table 7). 따라서, $\mathrm{LP}$ 저해능은 $100 \mu \mathrm{g} / \mathrm{mL}$ 와 $120 \mu \mathrm{g} / \mathrm{mL}$ 에서 각각 $25.4 \%(P<0.01)$ 와 $37.3 \%$ 로 이는 대조군에 비하여 유의한 저해능을 나타냈으며 $(P<0.001)$, 특히 추출물 $120 \mu \mathrm{g} / \mathrm{mL}$ 의 농도에서는 양성대조군인 quercetin 저해능인 $79.7 \%(P<$ $0.001)$ 의 $45 \%$ 이상인 것으로 나타났다(Fig. 4). AT 추출물 에 대한 LP 활성 사후분석 결과 quercetin, $120 \mu \mathrm{g} / \mathrm{mL} \mathrm{AT}$ 추출물, $100 \mu \mathrm{g} / \mathrm{mL}$ AT 추출물, 대조군 순으로 $\mathrm{LP}$ 저해능이 높은 것으로 나타났다. 이는 본 연구에서 $\mathrm{AT}$ 추출물의 높 
Table 7. The lipid peroxidation (LP) activity of Aster tataricus L. (AT) extract determined at a wavelength of $500 \mathrm{~nm}$

\begin{tabular}{lccccc}
\hline \hline $\begin{array}{c}\text { Concentrations } \\
\text { of AT extract } \\
(\mu \mathrm{g} / \mathrm{mL})\end{array}$ & $\begin{array}{c}\text { LP activity } \\
(500 \mathrm{~nm})\end{array}$ & $F$ & $P$ & $\begin{array}{c}\text { Tukey } \\
\text { HSD }\end{array}$ \\
\cline { 2 - 2 } & $\begin{array}{c}\text { Mean } \pm \mathrm{SD} \\
\text { Control }^{\mathrm{a}}\end{array}$ & & & \\
Positive control $^{\mathrm{b}}$ & $0.59 \pm 0.01$ & & & \\
$100^{\mathrm{c}}$ & $0.12 \pm 0.01$ & & & \\
$120^{\mathrm{d}}$ & $0.44 \pm 0.02$ & 1873.52 & $<.001$ & $\mathrm{a}>\mathrm{c}>\mathrm{d}>\mathrm{b}$ \\
\hline
\end{tabular}

The data indicate the mean \pm SD for triplicate experiments Abbreviation: Positive control: $25 \mu \mathrm{M}$ quercetin $\left(\mathrm{XTT}_{50}\right)$; AT, Aster tataricus L.; querce, Quercetin; LP, Lipid peroxidation

은 전저공여능과 함께 항산화능이 있음을 증명해 주고 있 다(Kikuzaki and Nakatani, 1993).

\section{고 찰}

브롬산나트륨 $\left(\mathrm{NaBrO}_{3}\right)$ 은 중금속을 포함하고 있는 모발 염색의 산화제로서 동일한 산화제인 과산화수소 $\left(\mathrm{H}_{2} \mathrm{O}_{2}\right)$ 와 같이 강한 독성으로 인해 접촉 시 피부세포에 손상을 초 래함으로써 접촉성 피부염의 알러젠으로도 알려져 있다 (Heidi et al., 2004). 일상생활 중에 자주 노출됨에도 불구하 고 생체에서의 피부독성에 대한 연구는 있으나(Kim et al., 2014), 세포수준에서 $\mathrm{NaBrO}_{3}$ 의 피부독성에 대한 정량적 분석은 물론, 독성기전에 대한 연구도 드물다(Santesson and Wickberg, 1913). 따라서, 본 연구에서는 $\mathrm{NaBrO}_{3}$ 에 대 한 세포독성을 알아보기 위하여 배양 NIH3T3 섬유아세 포에 22 55 $\mu \mathrm{M}$ 의 $\mathrm{NaBrO}_{3}$ 를 각 농도를 처리한 결과 처리 농도에 비례하여 세포생존율이 유의하게 감소됨으로써 세 포독성을 나타냈으며, 이 과정 중에 $\mathrm{XTT}_{50}$ 값이 $54.4 \mu \mathrm{M}$ 로 나타나 Borenfreund and Puerner (1985)의 독성판정기준 에 따라 고독성(highly-toxic)인 것으로 나타났다. 이들에 의하면 검정화학약제의 중앙값 $\left(\mathrm{XTT}_{50}\right)$ 이 $100 \mu \mathrm{M}$ 이하이 면 고독성(highly-toxic)으로 $2,000 \mu \mathrm{M}$ 이상이면 무독성 (non-toxic)으로 판정하기 때문이다. 이같은 결과는 아마도 $\mathrm{NaBrO}_{3}$ 의 독성에 산화적 손상과 관련된 수산기 $(-\mathrm{OH})$ 에 의해 guanine이 산화된 결과 8-oxodG의 형성과 함께 자유 라디칼을 생성해 세포 내 DNA에 손상을 주어 세포퇴화 를 초래하였거나(Kawanish and Murata, 2006), $\mathrm{NaBrO}_{3}$ 의 독 성이 세포 내 enolase 1 (Eno 1)이나 triosephosphate isomerase 1 (Tpi1)과 같은 glycolytic protein의 이상발현을 유도 함으로써 세포퇴화를 유도해 세포생존율의 감소를 나타
냈을 가능성을 배제할 수는 없다(Ahlbom et al., 2009). 그러 나 $\mathrm{NaBrO}_{3}$ 의 자유라디칼에 의한 산화적 손상 원인이 더 클 것으로 생각된다. 이 같은 근거의 하나로, 납이나 크롬 과 같은 몇몇 중금속화합물들이 이들의 반응과정 중에 자 유라디칼을 발생시킴으로써 독성과 산화적 손상과의 관 련성이 제시된 바 있다(Leonard et al., 2000). 따라서, 본 연 구에서는 $\mathrm{NaBrO}_{3}$ 의 독성과 자유라디칼간 산화적 손상과 의 연관성을 알아보기 위하여, 배양세포에 $\mathrm{XTT}_{50}$ 농도의 $\mathrm{NaBrO}_{3}$ 를 처리하기 전에 자유라디칼 제거제인 quercetin 을 2시간 동안 처리한 결과 $\mathrm{NaBrO}_{3}$ 만의 처리에 비하여 quercetin의 처리군에서 유의한 세포생존율의 증가를 나타 냈다. 이 같은 현상은 $\mathrm{NaBrO}_{3}$ 에 의한 자유라디칼을 quercetin이 제거함으로써 $\mathrm{NaBrO}_{3}$ 의 독성을 방어한 것으로, $\mathrm{NaBrO}_{3}$ 의 독성이 산화적 손상과 관련이 있음을 증명하였 다. 본 연구결과는 초산납이나 또는 삼산화크롬과 같은 중금속화합물의 독성이 vitamin $\mathrm{E}$ 와 같은 항산화제에 의해 방어됨으로써 이들 독성이 산화적 손상과 관련이 있다는 연구 보고와도 일맥 상통함을 알 수 있었다(Jung et al., 2014). 개미취(AT)의 항염 효과에 대해서는 interleukin (IL)$1,6,10,18$ 과 같은 사이토카인을 비롯하여 TNF- $\alpha$ 나 NF$\kappa \mathrm{B}, \mathrm{iNO}$ 또는 $\mathrm{COX}-2$ 와 같은 발현 등에 관한 연구를 볼 수 있다(Du et al., 2017). 또한 AT 추출물의 항산화 효과에 대해서는 동물조직(Yao et al., 2010; Hu et al., 2017)과 간세포 이나 비만세포, 대식세포 등에서 $\mathrm{SOD}, \mathrm{GSH}, \mathrm{CAT}$ 와 같은 효소분석 및 DPPH-radical 소거능에 대한 소수의 연구들 을 볼 수 있다(Ngabire et al., 2018). 따라서, AT 추출물에 대 한 더 많은 항산화 분석 필요성은 물론, 동시에 다양한 세 포종에서의 분석연구가 더욱 요구된다. 본 연구에서는 이 같은 취지의 일환으로 피부의 배양 NIH3T3 섬유아세포를 재료로 AT 추출물의 항산화능을 조사하였다. 먼저 $\mathrm{NaBrO}_{3}$ 의 산화적 손상독성에 대한 $\mathrm{AT}$ 추출물의 영향을 조사하 기 위하여 배양세포에 $\mathrm{XTT}_{50}$ 농도의 $\mathrm{NaBrO}_{3}$ 를 처리하기 전에 추출물 $100 \mu \mathrm{g} / \mathrm{mL}$ 와 $120 \mu \mathrm{g} / \mathrm{mL}$ 농도를 각각 전 처리 한 결과 $\mathrm{NaBrO}_{3}$ 만의 처리인 $41.6 \%$ 에 비하여 각각 $52.8 \%$ 와 $69.7 \%$ 로 유의한 세포생존율의 증가를 보였다. 본 결과 는 $\mathrm{AT}$ 추출물이 $\mathrm{NaBrO}_{3}$ 의 독성을 방어하였음을 말해 주 고 있으며, $\mathrm{AT}$ 와 같이 quercetin이나 flavonol, saponin과 같은 유사성분을 함유하고 있는 지금초(Euphorbiae humifusae L.) 추출물이나 한련초(Eclipta prostrate L.)이 초산납 이나 망간의 산화적 손상방어에 대한 보고와도 일치함을 알 수 있었다(Lee and Seo, 2018; Lee et al., 2018). 본 연구에 서 AT 추출물에 대한 함량 조사에서 폴리페놀과 플라보 
노이드의 함량이 각각 $46.8 \mathrm{mg} / \mathrm{g}$ 과 $23.9 \mathrm{mg} / \mathrm{g}$ 으로 나타났 다. 이는 지금초 추출물 $(51.2 \mathrm{mg} / \mathrm{g}, 26.5 \mathrm{mg} / \mathrm{g})$, 한련초 추출 물 $(51.4 \mathrm{mg} / \mathrm{g}, 25.9 \mathrm{mg} / \mathrm{g})$ 과 비교해 볼 때 거의 비슷한 것으 로 나타났다. 한편, $\mathrm{NaBrO}_{3}$ 의 산화적 손상독성에 대하여 $\mathrm{AT}$ 추출물은 보호효과를 보였는데, 이는 본 연구에서 시 행한 함량분석과 같이 AT 추출물에 항산화능이 강한 폴 리페놀과 플라보노이드계통의 saponin을 비롯한 qucertin 이나 kaempferol과 같은 성분이 다량 함유되어 있어 이들 성분들의 단독 또는 상호작용에 기인한 것으로 생각된다 (Ng et al., 2003). 이처럼 AT 추출물과 유사성분을 가지고 있는 추출물들이 자유라디칼에 대하여 유사한 보호 효과 를 보이는 것은 분석방법의 차이나 세포종에 따라 다소 다를 수는 있겠으나 모든 논문에서의 보고처럼 추출물에 함유된 비슷한 성분들의 약리활성 결과 때문인 것으로 간 주된다. 따라서 추출물의 어느 특정성분과 목표세포(target cell)의 수용체와 관련해 검정약물의 효능차이에 대한 후 속 연구가 필요할 것으로 생각된다. 한편, 본 연구에서 AT 추출물에 대한 항산화능을 조사한 결과 AT 추출물은 높 은 전자공여능(ED ability)과 지질과산화 저해능(inhibitory ability of LP)을 보임으로서 항산화능을 가지고 있음을 알 수 있었다. 본 결과는 초산납이나 망간독성의 산화적 손 상에 대한 지금초 추출물과 한련초 추출물의 항산화 분 석 결과와도 일치하였으며(Lee and Seo, 2018; Lee et al., 2018), AT 추출물 성분인 quercetin과 kaempferol이 LP 저해 능을 나타냈다는 보고와도 일치하였다(Ng et al., 2003). 전 자공여능은 자유라디칼에 전자를 공여하여 산화를 억제 하는 능력 즉, 자유라디칼을 제거하는 능력을 말하는데 이것은 DPPH-raedical 소거능을 의미한다(Blois, 1958). LP 저해능은 막지질을 주로 구성하고 있는 인지질의 산화를 방어하는 능력으로서 세포 내부를 싸고 있는 막보호라는 중요한 역할을 수행한다, 막의 파괴는 세포의 세포소기관 을 비롯한 모든 내부기능이 정지됨으로써 세포는 사멸하 게 된다(Kikuzaki and Nakatani, 1993). 그러나, 천연성분에 대한 약리활성이나 효능에 대한 더욱 자세한 규명을 위해 서는 약리나 생화학적과 같은 다양한 측면에서 연구가 체 계적으로 이루어져야 할 것으로 생각된다.

\section{ACKNOWLEDGEMENT}

None.

\section{CONFLICT OF INTEREST}

The authors declare no conflict of interest.

\section{REFERENCES}

Ahlbom GS, Delker DA, Roop BC, Winnick WM. Early alterations in protection and gene expression in rat kidney following bromate exposure. Food and Chemical Toxicology. 2009. 47: 1154-1160.

A.O.A.C. Official method of analysis. 18th ed. Washington DC: Association of official analytical chemists. 2005. pp. 21-21.

Blois MS. Antioxidant determination by the use of a stable free radical. Nature. 1958. 181: 1199-1200.

Borenfreund E, Puerner JA. A simple quantitative procedure using monolayer culture for cytotoxicity assay (HTD/NR-90). Journal of Tissue Culture Methods. 1985. 9: 7-9.

Chun HJ, Choi WH, Baek SH, Woo WH. Effect of quercetin on melanogenesis in melanocyte cells. Korean Journal of Pharmacognosy. 2002. 33: 245-251.

Choi DY, Choi EJ, Jin QL, Shin JE, Woo ER. Biochemical activity of flavonoids isolated from Aster tataricus. Korean Journal of Pharmacognosy. 2009. 40: 123-127.

Du L, Mei HF, Yin X, Xing YQ. Delayed growth of glioma by a polysaccharide from Aster tataricus involve upregulation of $\mathrm{Bax} / \mathrm{Bcl}-2$ ratio, activation of caspase-3/8/9, and downregulation of the Akt. Tumor Bioliogy. 2014. 35: 1819-1825.

Eo SH, Kim HR, Kim KY. A comparative analysis of wave formation and preservation by treatment with sodium bromate and hydrogen peroxide as oxidant of permanent wave. Journal of Investigative Cosmetology. 2011. 7: 449-457.

Guo TL, McCay JA, Karrow NA, Brown RD, White Jr KL. Immunotoxicity of sodium bromate in female B6C3F1 mice: a 28day drinking water study. Drug and Chemical Toxicology. 2001. 24: 129-149.

Heidi S, Suresh CR, Ksaus EA, Jeanne DJ, Torkil M. Hair dye contact allergy: quantitative exposure assessment of selectied products and clinical cases. Contact Dermatitis. 2004. 50: 344 -348 .

Hu BL, Hou WC, Li XP, Ma LJ, Bai XX, Liu Q, Liu BH. Aster tataricus attenuates the neuronal cell damaged and restores the cognitive fuctions in epileptic rat. Biochemical Research. 2017. 28: 187-195.

Jung JY, Oh SK, Park SH, Yoon MY, Yu YW, Rim YS, et al. Antioxidative effect of Ajuga multiflora BUNGE extract on chromium trioxide, dermatitis inducer in cultured NIH3T3 fibroblasts. Journal of Investigative Cosmetology. 2014. 10: 
21-26. https://doi.org/10.15810/jic.2014.10.1.003.

Kawanish S, Murata M. Mechanism of DNA damage induced by bromate differ from general type of oxidative stress. Toxicology. 2006. 221: 172-178.

Kim M, Lee SB, Kim KY. Using behaviors of permanent wave neutralizers, skin disorder and it's treatment in hairdressers. Journal of Korean Society of Cosmetology. 2014. 20: 528-536.

Kikuzaki H, Nakatani N. Antioxidant effects of some ginger constituents. Journal of Food Science. 1993. 58: 1407-1410. https://doi.org/10.1111/j.1365-2621.1993.tb06194.x

Kolisetty N, Bull RJ, Muralidhara S, Cumming BS. Association of bromated proteins and changes in protein expression in rat kidney with subcarcinogenic doses of bromate. Toxicology and Applied pharmacology. 2013. 272: 391-398.

Kolli RT, Glenn TC, Brown BT, Kaura SP. Bromate-induced changes in p21 DNA methylation and histon acetylation in renal cells. Toxicological Sciences. 2019. 168: 460-473.

Lee SH, Seo YM. Alleviating effects of Euphorbiae humifusae L. extract on the neurotoxicity induced by lead. Korean Journal of Clinical Laboratory Science. 2018. 50: 501-510. https:// doi.org/10.15324/kjcls.2018.50.4.501

Lee GY, Chang BS. Stydies on the tensile strength of oxidative permanent dye hair. Korean Journal of Microscopy. 2008. 38: 339-345.

Lee SH, Jung IJ, Jang HS. The antioxidative effect of Eclipta prostrate L. extract on cultured NIH3T3 fibroblasts induced by manganese-induced cytotoxicity. Biochemical Science Science Letters. 2018. 24: 1-8.

Leonard S, Wang S, Zhang L, Castranova V, Vallyathan V, Shi X. Role of molecular oxygen in the generation of hydroxyl and superoxide anion radicals during enzymatic $\mathrm{Cr}$ (VI)-induced carcinogenesis. Journal of Environmental Pathology, Toxicology, and Oncology. 2000. 19: 49-60.

Mosmann T. Rapid colorimetric assay for cellular growth and survival: application to proliferation and cytotoxicity assays. Journal of Immunological Methods. 1983. 65: 55-63.

$\mathrm{Ng} \mathrm{TB}$, Liu F, Lu Y, Cheng CHK, Wang Z. Antioxidant activity of compounds from medicinal herb Aster tataricus. Comparative Biochemistry \& Phsiology. 2003. 136: 109-115.

Ngabire D, Seong YA, Patil MP, Niyonizigiye I, Seo YB, Kim GD. Anti-inflammatory effects of Aster incisus through the inhibition of NF-kB, MARK and Akt pathways in LPS-stimulated
Raw 264.7 macrophages. Mediators of Inflammation. 2018. 18: $26-36$.

Nieva Moreno MI, Isla MI, Sampietro AR, Vattuone MA. Comparison of the three radical-scavenging activity of propolis from several regions of Argentina. Journal of Ethmopharmacology. 2000. 71: 109-114. https://doi.org/10.1016/S03788741(99)00189-0

Park SH, Kim KH, Kim JG, Song JE, Oh WG, Kim JH, Lee KY. A case of severe acute renal failure due to sodium bromate intoxication. Korean Journal of Nephrology. 2011. 30: 84-86.

Ryu DM, Jang SM, Park JW. Acute kidney injury due to sodium bromate intoxication: a report of two cases. Korean Journal of Internal Medicine. 2011. 26: 453-465.

Santesson CC, Wickberg. The action of sodium bromate. Skandinav Arch Physiology. 1913. 30: 337-374.

Sashiyama H, Irie Y, Ohtake Y, Okuta K, Acute renal failure and hearing loss due to sodium bromate poisoning: a case report and review of the literature. Clinical Literature. 2002. 58: 455 $-457$.

Suzuki J, Takanashi Y, Koyama A, Katori Y. Journal of Laryngology and Otology. 2018. 132: 1039-1041.

Wang L, Li MD, Cao PP, Zhang CF, Huang F, Zhang M. Astin B, a cyclic pentapeptide from Aster tataricus induces apoptosis and autophagy in human hepatic L-02 cells. Chemicobiological Interactions. 2014. 223: 1-9.

Yang H, Shi H, Zhang Q, Liu Y, Wan C, Zhang L. Stimultaneous determination of five components in Aster tataricus bt ultra performance liquid chromatography-Tandem mass spectrometry. Journal of Chromatographic Science. 2015. 54: 500 $-506$.

Yao X, Dong X, Zhang HS, Wang Y, Liu XS. Preventive effect of Aster tataricus on oxidative stress and biomarker of renal function in rat fed with high fat diet and sucrose diet. Biomedical Research. 2017. 28: 1647-1653.

https://doi.org/10.15616/BSL.2019.25.4.348

Cite this article as: Chung $\mathrm{JH}$, Lee GW, Seo YM. Protective Effect of Aster tataricus L. Extract on the Dermal Cytotoxicity Induced by Sodium Bromate, Oxidant of Hair Dye. Biomedical Science Letters. 2019. 25: 348-356. 